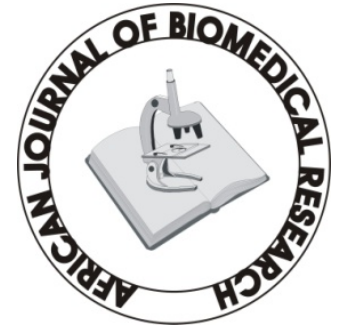

Full-text available at http://www.ajbrui.com http://www.bioline.br/md http://www.ajol.com

Received:

June 2007

Accepted (Revised): October 2007

Published January 2008
Full Length Research Article

\section{Enzyme Activities and Histopathology of Selected Tissues in Rats Treated with Potassium bromate.}

\author{
Akanji, M. A., Nafiu, M. O. and *Yakubu, M. T. \\ Department of Biochemistry, University of Ilorin, \\ PMB 1515, Ilorin, Nigeria.
}

\begin{abstract}
The effect of chronic administration of potassium bromate $\left(\mathrm{KBrO}_{3}\right)$, a flour improver, on some 'marker' enzymes of rat cellular system was investigated. The levels of these enzymes were measured progressively in the kidney, liver and small intestine, 24h after days 1, 3, 5, 10, 15 and 20 following the administration of $10 \mathrm{mg} / \mathrm{kg}$ body weight of potassium bromate and when left for 10days without administration after their 20 daily doses. The alkaline phosphatase (ALP), lactate dehydrogenase (LDH) and glutamate dehydrogenase $(\mathrm{GDH})$ activities of all the tissues were significantly $(\mathrm{P}<0.05)$ decreased in $\mathrm{KBrO}_{3}$ treated groups with corresponding significant $(\mathrm{P}<0.05)$ increase in the serum enzymes. Acid phosphatase (ACP) activities of all the tissues as well as the serum enzyme activities were significantly $(\mathrm{P}<0.05)$ decreased. There was only recovery in the ACP activities of all the tissues. Histological examination revealed congestion of the central vein with blood cells in the hepatocytes, infiltration of the interstitial cells accompanied with acute nephritis in the nephrons and mild mucosal dysfunction in the small intestine. The alterations in the 'marker' enzymes as well as in the tissue histology are indications of adverse effect of potassium bromate on the cells which might be due to the presence of oxygen in the molecule leading to oxidation of polyunsaturated fatty acids on the ordered lipid bilayer of cell membranes. All these might be responsible for the various adverse effects associated with the chemical compound.
\end{abstract}

(Afr. J. Biomed. Res. 11: 87- 95)

Key Words; Potassium bromate, Chronic, Marker enzymes, Histology, Oxidation, Polyunsaturated fatty acids, Cell membrane

*Address for Correspondence: tomuyak@yahoo.com; tomuyak@gmail.com

Abstracted by:

African Index Medicus (WHO), CAB Abstracts, Index Copernicus, Global Health Abstracts, Asian Science Index, Index Veterinarius, Bioline International , African Journals online 


\section{INTRODUCTION}

Potassium bromate $\left(\mathrm{KBrO}_{3}\right)$, a white crystalline solid and a widely reactive food additive (WHO, 1996) is often used in bakeries as flour improver where it enables loaves with high volume qualities to be produced from low protein wheat. It also help to produce bread with a fine crumb structure and prevents dough from falling when dough is handled between proofing and baking, yielding higher bread volume (Kurokawa et al., 1990).

Studies have shown that potassium bromate has harmful effects on the nutritional qualities of bread by lowering vitamins $A_{1}, B_{1}, B_{2}, E$ and niacin, the main vitamins in bread (Laba, 2003). Studies have also shown that it possess the potential of inducing cancer, kidney failure, deafness, redness and pains of the eye and skin (Mack, 1988; De Angelo et al., 1998). The unique reactivity of bromate has given rise to a wealth of speculations as to its potential toxicity which led to its ban by NAFDAC (the regulatory body on the use of chemicals in Nigeria).

In the present report, we have decided to provide information on the mode of cellular toxicity of potassium bromate by assaying for the activities of some carefully selected 'marker' enzymes (alkaline and acid phosphatases, lactate and glutamate dehydrogenases) of cellular damage in rats, since it has been shown that the site of injury to the cell could be correlated and determined by assaying the level of activities of 'marker' enzyme in such cells (Ngaha, 1981). The levels of these enzymes were also assayed in the serum to correlate the changes in the tissues to that of the serum (Ngaha, 1982; Akanji and Yakubu, 2000) and these were complemented with histological examination of the selected tissues.

\section{MATERIALS AND METHODS}

A total of seventy white albino rats (Rattus norvegicus) of Wistar strain with average weight of $200 \pm 5 \mathrm{~g}$ were obtained from small Animal Holding Unit of the Department of Biochemistry, University of Ilorin, Ilorin, Nigeria. Assay kits for ALP, ACP and GDH were obtained from Randox
Laboratories Ltd, UK while that of LDH was from Quinica Aplicada, S. A. Spain. Potassium bromate was obtained from open market at Agege, Lagos State, Nigeria. All other reagents used were of analytical grade and were prepared in all glassdistilled water. The reagents were stored in reagent bottles except biuret which was stored in plastic container (Plummer, 1978).

\section{Animal grouping and administration of potassium bromate}

The animals were housed in metabolic cages under standard conditions (12h light/12h dark, $28^{\circ} \mathrm{C} \pm 3^{\circ} \mathrm{C}$ and $40-55 \%$ humidity). They were allowed free access to normal rat chow and tap water. The acclimatization was done for two weeks before the start of the experiment. The animal grouping consisted of two groups of 35 animals each as follows:

A - rats that were orally administered with $1 \mathrm{ml}$ of distilled water (the control group)

B - rats that were administered with $10 \mathrm{mg} / \mathrm{kg}$ body weight (p.o) of potassium bromate (the test group).

Animals in groups A and B were administered with their appropriate doses on daily basis for 20days. 5 rats each from A and B groups were sacrificed 24hr after days 1, 3, 5, 10, 15 and 20 daily doses while the remaining 5 in $\mathrm{A}$ and $\mathrm{B}$ groups were left for 10days without any administration after their initial 20 daily doses of distilled water and potassium bromate respectively.

\section{Preparation of serum and tissue homogenates}

Under ether anaesthesia, the neck area was quickly cleared of fur and skin to expose the jugular veins. The veins after being slightly displaced (to avoid contamination with interstitial fluid) (Yakubu et al., 2005) were sharply cut with a sterile scapel blade and blood was collected into clean, dry centrifuge tubes and allowed to clot for $30 \mathrm{~min}$. This was then centrifuged at $33.5 \times g$ for 15 min (Yakubu et al., 2005) using Uniscope Laboratory Centrifuge (model SM800B, Surgifriend Medicals, Essex, England). The sera were thereafter aspirated using Pasteur pipettes into clean, dry, sample bottles and were then 
stored frozen overnight before being used for the enzyme assay.

The animals were quickly dissected and the organs (liver, kidney and small intestine) removed. The kidney was decapsulated while the small intestine was cleaned of metabolic waste. They were thereafter blotted with clean tissue paper, weighed and homogenized in $0.25 \mathrm{M}$ sucrose solution $(1: 5 \mathrm{w} / \mathrm{v})$. The homogenates were transferred into specimen bottles and kept frozen for 24hours before being used for the analyses.

\section{Determination of enzyme activities and protein concentration}

Alkaline phosphatase (EC 3.1.3.1) and acid phosphatase (EC 3.1.3.2) activities were determined according to the methods described by Wright et al (1972a and b) respectively. Lactate dehydrogenase (EC. 1.1.1.27) and glutamate dehydrogenase (EC 1.4.1.2) activities were determined as described by Wroblewski and La Due (1955) and Schmidt et al (1965) respectively. Protein concentration was estirmated by biuret method as described by Gornal et al (1949). All measurements were done using Spectronic 21 spectrophotometer (Bausch and Lomb, NY).

\section{Histological examination}

The preparation of tissues for histological examination was done as described by Krause (2001); the photomicrographs were observed using the Leitz, DIALUX research microscope at x200.

\section{Statistical Analysis}

Data are mean of 5 replicates \pm SD. Duncan Multiple Range Test was used to account for the differences among different means as well as the interaction between the variables. Differences were considered statistically significant at $\mathrm{P}<0.05$ (Mahajan, 1997).

\section{RESULTS}

The effects of administration of $10 \mathrm{mg} / \mathrm{kg}$ body weight of $\mathrm{KBrO}_{3}$ on the activities of ALP, ACP, $\mathrm{LDH}$ and GDH of selected rat tissues and serum are shown in Tables 1-4 respectively.
There was an immediate increase $(\mathrm{P}<0.05)$ in ALP activity of all the tissues studied right from after the first dose of potassium bromate administration (Table 1). However, this was not sustained any further as enzyme activity decreased significantly $(\mathrm{P}<0.05)$ in all the tissues throughout the period of administration and by the last day of administration, the enzyme activity had reduced to about half the control value in all the tissues. The 10days recovery period did not produce any deviation from the reduction in the enzyme activity observed during the treatment period. The significant reduction $(\mathrm{P}<0.05)$ in tissues ALP activities was accompanied by corresponding significant $(\mathrm{P}<0.05)$ increase in the serum enzyme right from after the third day and was sustained throughout the experimental period (Table 1).

ACP activities in all the tissues were significantly increased $(\mathrm{P}<0.05)$ with no significant change in the serum enzyme $(\mathrm{P}>0.05)$ throughout the period of administration when compared with the control. The recovery period had their enzyme activity return towards their control values (Table 2)

LDH activities were significantly reduced $(\mathrm{P}<0.05)$ in all the tissues studied dropping to about one-third the control values in the liver and kidney by the end of administration (Table 3 ). The significant increases $(\mathrm{P}<0.05)$ noticed in the kidney and small intestine from after the single dose persisted only in the kidney up till after the third daily doses. The recovery period revealed similar reduction in the $\mathrm{LDH}$ activities of all the tissues. There was also concomitant increase $(\mathrm{P}<0.05)$ in the serum enzyme from after the first dose (Table 3)

GDH activities in the rat liver and small intestine increased from after the single dose of potassium bromate administration and were sustained till the end of three daily doses (Table 4). Thereafter, the GDH activities continued to decrease up till the end of potassium bromate administration. In the contrary, kidney GDH increased significantly $(\mathrm{P}<0.05)$ throughout the experimental period. 
Table 1:

Effect of chronic administration of potassium bromate on alkaline phosphatase (ALP) activities of selected rat tissues and serum

\begin{tabular}{|c|c|c|c|c|c|c|c|c|}
\hline \multirow[t]{2}{*}{ Days } & \multicolumn{2}{|c|}{ LIVER } & \multicolumn{2}{|c|}{ KIDNEY } & \multicolumn{2}{|c|}{ SMALL INTESTINE } & \multicolumn{2}{|c|}{ SERUM } \\
\hline & Control & Test & Control & Test & Control & Test & Control & Test \\
\hline 1 & $1.54 \pm 0.02^{\mathrm{a}}$ & $1.90 \pm 0.04^{b}$ & $14.20 \pm 2.11^{\mathrm{a}}$ & $17.50 \pm 1.24^{\mathrm{b}}$ & $12.55 \pm 2.41^{\mathrm{a}}$ & $19.20 \pm 2.24^{b}$ & $0.12 \pm 0.01^{\mathrm{a}}$ & $0.20 \pm 0.03^{\mathrm{b}}$ \\
\hline 3 & $1.52 \pm 0.01^{\mathrm{a}}$ & $1.53 \pm 0.01^{\mathrm{a}}$ & $14.17 \pm 1.20^{\mathrm{a}}$ & $8.64 \pm 1.01^{\mathrm{C}}$ & $12.10 \pm 2.70^{\mathrm{a}}$ & $7.04 \pm 1.22^{\mathrm{C}}$ & $0.12 \pm 0.02^{\mathrm{a}}$ & $0.18 \pm 0.01^{\mathrm{C}}$ \\
\hline 5 & $1.55 \pm 0.09^{\mathrm{a}}$ & $0.70 \pm 0.02^{\mathrm{C}}$ & $14.21 \pm 0.87^{\mathrm{a}}$ & $6.04 \pm 0.11^{\mathrm{d}}$ & $12.48 \pm 1.97^{\mathrm{a}}$ & $8.01 \pm 0.26^{\mathrm{C}}$ & $0.11 \pm 0.03^{\mathrm{a}}$ & $0.15 \pm 0.01$ \\
\hline 10 & $1.58 \pm 0.07^{\mathrm{a}}$ & $0.40 \pm 0.01^{\mathrm{d}}$ & $13.85 \pm 2.31^{\mathrm{a}}$ & $5.15 \pm 0.21^{\mathrm{d}}$ & $12.51 \pm 1.09^{\mathrm{a}}$ & $8.41 \pm 0.51^{\mathrm{C}}$ & $0.12 \pm 0.01^{\mathrm{a}}$ & $0.21 \pm 0.01^{b}$ \\
\hline 15 & $1.57 \pm 0.10^{\mathrm{a}}$ & $0.90 \pm 0.02^{\mathrm{e}}$ & $14.19 \pm 0.54^{\mathrm{a}}$ & $7.21 \pm 0.18^{\mathrm{C}}$ & $12.50 \pm 2.05^{\mathrm{a}}$ & $6.21 \pm 0.48^{\mathrm{d}}$ & $0.12 \pm 0.01^{\mathrm{a}}$ & $0.19 \pm 0.02^{b}$ \\
\hline 20 & $1.56 \pm 0.08^{\mathrm{a}}$ & $0.50 \pm 0.02^{\mathrm{d}}$ & $14.17 \pm 2.10^{\mathrm{a}}$ & $4.32 \pm 0.32^{\mathrm{e}}$ & $12.54 \pm 2.10^{\mathrm{a}}$ & $5.66 \pm 0.05^{\mathrm{d}}$ & $0.11 \pm 0.03^{\mathrm{a}}$ & $0.35 \pm 0.04^{e}$ \\
\hline 30 & $1.57 \pm 0.06^{\mathrm{a}}$ & $0.20 \pm 0.01^{\mathrm{f}}$ & $14.19 \pm 0.77^{\mathrm{a}}$ & $10.22 \pm 1.02^{f}$ & $12.57 \pm 2.00^{\mathrm{a}}$ & $3.14 \pm 0.22^{\mathrm{e}}$ & $0.11 \pm 0.02^{\mathrm{a}}$ & $0.29 \pm 0.02^{f}$ \\
\hline
\end{tabular}

Values are mean of 5 replicates \pm SD; Enzyme activity is expressed in $\mathrm{nM} / \mathrm{min} / \mathrm{mg}$ protein

Test values carrying superscripts different from their control and different each other for each tissue and serum are significantly different (P<0.05).

Table 2:

Effect of chronic administration of potassium bromate on acid phosphatase (ACP) activities of selected rat tissues and serum

\begin{tabular}{|c|c|c|c|c|c|c|c|c|}
\hline \multirow[t]{2}{*}{ Days } & \multicolumn{2}{|c|}{ LIVER } & \multicolumn{2}{|c|}{ KIDNEY } & \multicolumn{2}{|c|}{ SMALL INTESTINE } & \multicolumn{2}{|c|}{ SERUM } \\
\hline & Control & Test & Control & Test & Control & Test & Control & Test \\
\hline 1 & $16.82 \pm 0.42^{\mathrm{a}}$ & $19.70 \pm 0.11^{b}$ & $24.00 \pm 3.21^{\mathrm{a}}$ & $39.20 \pm 3.17^{b}$ & $8.26 \pm 0.24^{\mathrm{a}}$ & $14.60 \pm 0.43^{b}$ & $0.34 \pm 0.02^{\mathrm{a}}$ & $0.16 \pm 0.01^{\mathrm{b}}$ \\
\hline 3 & $15.87 \pm 0.81^{\mathrm{a}}$ & $23.22 \pm 0.40^{\mathrm{C}}$ & $23.82 \pm 2.40^{\mathrm{a}}$ & $25.36 \pm 1.09^{\mathrm{a}}$ & $8.30 \pm 0.21^{\mathrm{a}}$ & $15.10 \pm 1.06^{\mathrm{b}}$ & $0.32 \pm 0.04^{\mathrm{a}}$ & $0.18 \pm 0.02^{b}$ \\
\hline 5 & $17.01 \pm 0.04^{\mathrm{a}}$ & $26.32 \pm 1.11^{d}$ & $21.88 \pm 5.53^{\mathrm{a}}$ & $33.70 \pm 1.07^{\mathrm{c}}$ & $8.25 \pm 0.22^{\mathrm{a}}$ & $11.21 \pm 0.30^{\mathrm{C}}$ & $0.33 \pm 0.03^{\mathrm{a}}$ & $0.30 \pm 0.01^{\mathrm{a}}$ \\
\hline 10 & $16.61 \pm 0.12^{\mathrm{a}}$ & $25.20 \pm 1.05^{\mathrm{d}}$ & $23.91 \pm 3.11^{\mathrm{a}}$ & $32.64 \pm 1.12^{\mathrm{c}}$ & $8.27 \pm 0.19^{\mathrm{a}}$ & $17.55 \pm 1.37^{\mathrm{d}}$ & $0.32 \pm 0.02^{\mathrm{a}}$ & $0.17 \pm 0.02^{\mathrm{b}}$ \\
\hline 15 & $16.70 \pm 0.50^{\mathrm{a}}$ & $27.61 \pm 2.04^{\mathrm{d}}$ & $24.03 \pm 3.54^{\mathrm{a}}$ & $35.40 \pm 2.66^{\mathrm{d}}$ & $7.96 \pm 0.75^{\mathrm{a}}$ & $20.60 \pm 2.14^{\mathrm{e}}$ & $0.34 \pm 0.01^{\mathrm{a}}$ & $0.12 \pm 0.01^{\mathrm{c}}$ \\
\hline 20 & $16.74 \pm 0.07^{\mathrm{a}}$ & $19.50 \pm 0.12^{b}$ & $23.70 \pm 2.50^{\mathrm{a}}$ & $29.69 \pm 1.00^{\mathrm{e}}$ & $8.14 \pm 0.86^{\mathrm{a}}$ & $16.74 \pm 1.27^{d}$ & $0.31 \pm 0.05^{\mathrm{a}}$ & $0.14 \pm 0.01^{\mathrm{c}}$ \\
\hline 30 & $16.80 \pm 0.05^{\mathrm{a}}$ & $16.60 \pm 1.03^{\mathrm{a}}$ & $23.60 \pm 0.47^{\mathrm{a}}$ & $23.29 \pm 3.02^{\mathrm{a}}$ & $7.80 \pm 0.54^{\mathrm{a}}$ & $8.44 \pm 0.12^{\mathrm{a}}$ & $0.33 \pm 0.01^{\mathrm{a}}$ & $0.13 \pm 0.01^{\mathrm{c}}$ \\
\hline
\end{tabular}

Values are mean of 5 replicates \pm SD; Enzyme activity is expressed in $\mathrm{nM} / \mathrm{min} / \mathrm{mg}$ protein

Test values carrying superscripts different from their control and different each other for each tissue and serum are significantly different (P<0.05). 
African Journal of Biomedical Research 2008 (Vol. 11) / Akanji, Nafiu and Yakubu

Table 3:

Effect of chronic administration of potassium bromate on lactate dehydrogenase (LDH) activities of selected rat tissues and serum

\begin{tabular}{|c|c|c|c|c|c|c|c|c|}
\hline \multirow[b]{2}{*}{ Days } & \multicolumn{2}{|c|}{ LIVER } & \multicolumn{2}{|c|}{ KIDNEY } & \multicolumn{2}{|c|}{ SMALL INTESTINE } & \multicolumn{2}{|c|}{ SERUM } \\
\hline & Control & Test & Control & Test & Control & Test & Control & Test \\
\hline 1 & $12.72 \pm 0.06^{\mathrm{a}}$ & $9.02 \pm 0.05^{b}$ & $154.60 \pm 9.31^{\mathrm{a}}$ & $172.00 \pm 8.22^{b}$ & $148.44 \pm 6.12^{\mathrm{a}}$ & $170.80 \pm 4.52^{b}$ & $7.10 \pm 0.17^{\mathrm{a}}$ & $9.17 \pm 0.11^{b}$ \\
\hline 3 & $12.55 \pm 0.40^{\mathrm{a}}$ & $8.09 \pm 0.07^{\mathrm{b}}$ & $153.65 \pm 8.11^{\mathrm{a}}$ & $115.21 \pm 7.10^{c}$ & $147.60 \pm 5.74^{\mathrm{a}}$ & $120.40 \pm 3.70^{c}$ & $7.12 \pm 0.12^{\mathrm{a}}$ & $10.55 \pm 1.01^{\mathrm{b}}$ \\
\hline 5 & $12.60 \pm 0.27^{\mathrm{a}}$ & $6.14 \pm 0.21^{\mathrm{C}}$ & $151.55 \pm 9.10^{\mathrm{a}}$ & $96.22 \pm 4.18^{\mathrm{d}}$ & $147.85 \pm 4.79^{\mathrm{a}}$ & $101.20 \pm 4.10^{\mathrm{c}}$ & $6.93 \pm 0.25^{\mathrm{a}}$ & $13.40 \pm 0.71^{\mathrm{c}}$ \\
\hline 10 & $12.63 \pm 0.09^{\mathrm{a}}$ & $4.63 \pm 0.25^{\mathrm{d}}$ & $153.59 \pm 8.76^{\mathrm{a}}$ & $79.21 \pm 4.41^{\mathrm{e}}$ & $148.42 \pm 7.03^{\mathrm{a}}$ & $87.05 \pm 2.38^{\mathrm{d}}$ & $7.02 \pm 0.42^{\mathrm{a}}$ & $15.27 \pm 0.32^{\mathrm{d}}$ \\
\hline 15 & $12.71 \pm 0.20^{\mathrm{a}}$ & $2.65 \pm 0.18^{\mathrm{e}}$ & $154.03 \pm 5.64^{\mathrm{a}}$ & $48.60 \pm 3.72^{f}$ & $146.70 \pm 7.85^{\mathrm{a}}$ & $109.20 \pm 4.60^{\mathrm{c}}$ & $7.14 \pm 0.08^{\mathrm{a}}$ & $16.42 \pm 0.09^{\mathrm{d}}$ \\
\hline 20 & $12.57 \pm 0.16^{\mathrm{a}}$ & $3.40 \pm 0.08^{\mathrm{e}}$ & $153.85 \pm 6.10^{\mathrm{a}}$ & $49.50 \pm 3.00^{f}$ & $148.50 \pm 5.70^{\mathrm{a}}$ & $61.21 \pm 3.60^{\mathrm{e}}$ & $6.89 \pm 0.39^{\mathrm{a}}$ & $11.34 \pm 0.20^{\mathrm{b}}$ \\
\hline 30 & $12.59 \pm 0.42^{\mathrm{a}}$ & $4.55 \pm 0.05^{\mathrm{d}}$ & $153.60 \pm 7.22^{\mathrm{a}}$ & $51.14 \pm 3.18^{f}$ & $147.60 \pm 5.63^{\mathrm{a}}$ & $49.24 \pm 4.97^{\mathrm{f}}$ & $7.13 \pm 0.17^{\mathrm{a}}$ & $10.03 \pm 0.07^{\mathrm{b}}$ \\
\hline
\end{tabular}

Values are mean of 5 replicates \pm SD; Enzyme activity is expressed in $\mathrm{nM} / \mathrm{min} / \mathrm{mg}$ protein

Test values carrying superscripts different from their control and different each other for each tissue and serum are significantly different ( $<<0.05)$.

Table 4:

Effect of chronic administration of potassium bromate on glutamate dehydrogenase (GDH) activities of selected rat tissues and serum

\begin{tabular}{|c|c|c|c|c|c|c|c|c|}
\hline \multirow[b]{2}{*}{ Days } & \multicolumn{2}{|c|}{ LIVER } & \multicolumn{2}{|c|}{ KIDNEY } & \multicolumn{2}{|c|}{ SMALL INTESTINE } & \multicolumn{2}{|c|}{ SERUM } \\
\hline & Control & Test & Control & Test & Control & Test & Control & Test \\
\hline 1 & $30.00 \pm 0.10^{\mathrm{a}}$ & $52.10 \pm 5.20^{b}$ & $26.00 \pm 2.55^{\mathrm{a}}$ & $77.21 \pm 5.19^{b}$ & $10.00 \pm 1.04^{\mathrm{a}}$ & $10.40 \pm 1.10^{\mathrm{a}}$ & $0.11 \pm 0.00^{\mathrm{a}}$ & $0.14 \pm 0.00^{b}$ \\
\hline 3 & $31.01 \pm 0.29^{\mathrm{a}}$ & $53.20 \pm 4.19^{b}$ & $24.87 \pm 4.09^{\mathrm{a}}$ & $41.25 \pm 2.11^{\mathrm{c}}$ & $10.61 \pm 1.08^{\mathrm{a}}$ & $12.25 \pm 0.09^{\mathrm{b}}$ & $0.10 \pm 0.02^{\mathrm{a}}$ & $0.17 \pm 0.01^{\mathrm{c}}$ \\
\hline 5 & $29.80 \pm 0.54^{\mathrm{a}}$ & $24.20 \pm 2.04^{c}$ & $25.34 \pm 2.07^{\mathrm{a}}$ & $37.21 \pm 2.10^{\mathrm{d}}$ & $10.75 \pm 1.00^{\mathrm{a}}$ & $6.01 \pm 0.20^{\mathrm{c}}$ & $0.10 \pm 0.00^{\mathrm{a}}$ & $0.18 \pm 0.01^{\mathrm{c}}$ \\
\hline 10 & $30.04 \pm 0.20^{\mathrm{a}}$ & $25.09 \pm 1.07^{c}$ & $26.07 \pm 1.87^{\mathrm{a}}$ & $42.40 \pm 2.07^{\mathrm{c}}$ & $11.05 \pm 0.09^{\mathrm{a}}$ & $6.04 \pm 0.16^{\mathrm{c}}$ & $0.10 \pm 0.02^{\mathrm{a}}$ & $0.25 \pm 0.02^{\mathrm{d}}$ \\
\hline 15 & $30.25 \pm 0.36^{\mathrm{a}}$ & $26.40 \pm 0.22^{\mathrm{c}}$ & $25.74 \pm 2.12^{\mathrm{a}}$ & $37.10 \pm 2.71^{\mathrm{d}}$ & $11.10 \pm 0.05^{\mathrm{a}}$ & $6.22 \pm 0.40^{\mathrm{c}}$ & $0.11 \pm 0.00^{\mathrm{a}}$ & $0.23 \pm 0.03^{\mathrm{d}}$ \\
\hline 20 & $30.07 \pm 0.14^{\mathrm{a}}$ & $20.21 \pm 1.02^{\mathrm{d}}$ & $26.07 \pm 2.10^{\mathrm{a}}$ & $36.50 \pm 2.08^{\mathrm{d}}$ & $10.50 \pm 0.30^{\mathrm{a}}$ & $4.14 \pm 0.09^{\mathrm{d}}$ & $0.10 \pm 0.01^{\mathrm{a}}$ & $0.27 \pm 0.01^{\mathrm{e}}$ \\
\hline 30 & $29.65 \pm 0.53^{\mathrm{a}}$ & $19.40 \pm 0.13^{\mathrm{d}}$ & $23.90 \pm 4.65^{\mathrm{a}}$ & $33.22 \pm 3.60^{\mathrm{e}}$ & $10.22 \pm 1.03^{\mathrm{a}}$ & $4.70 \pm 0.05^{\mathrm{d}}$ & $0.10 \pm 0.01^{\mathrm{a}}$ & $0.17 \pm 0.01^{\mathrm{c}}$ \\
\hline
\end{tabular}

Values are mean of 5 replicates $\pm \mathrm{SD}$; Enzyme activity is expressed in $\mathrm{nM} / \mathrm{min} / \mathrm{mg}$ protein

Test values carrying superscripts different from their control and different each other for each tissue and serum are significantly different $(\mathrm{P}<0.05)$. 
The serum GDH activity increased significantly $(\mathrm{P}<0.05)$ from after the three daily doses of potassium bromate and persisted throughout the experimental period (Table 4).

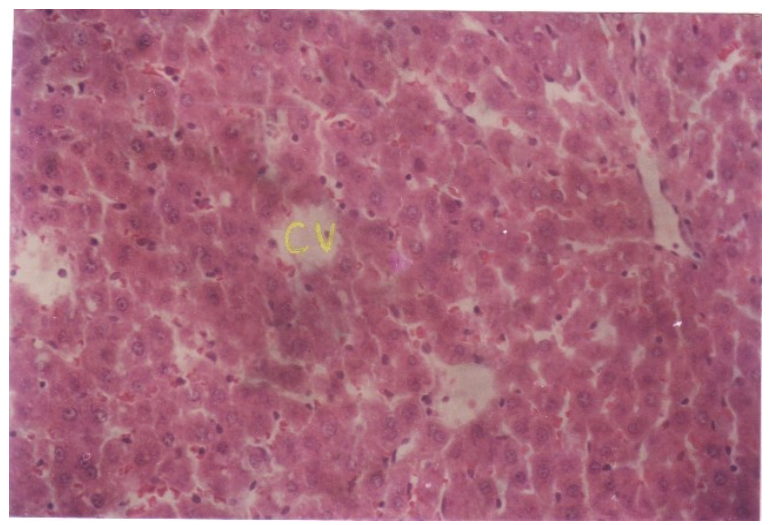

\section{Plate 1a:}

Photomicrograph of rat liver administered with distilled water (Control). The part marked $\mathbf{C V}$ is the central vein (mg x200)

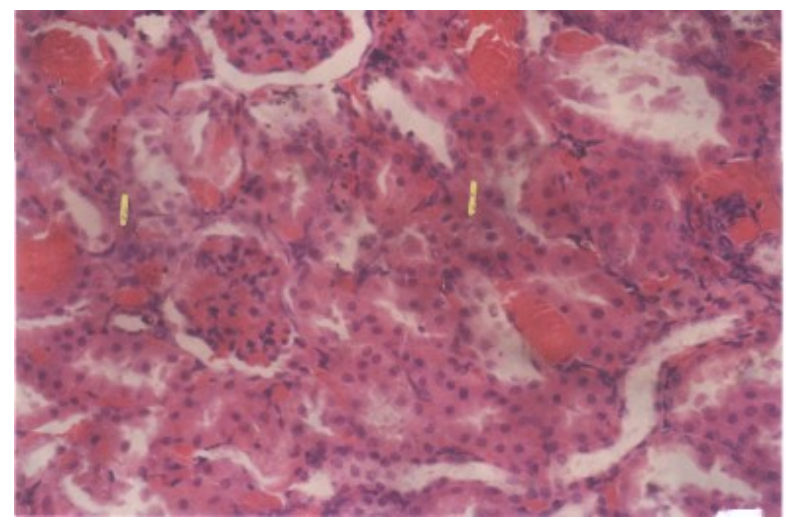

\section{Plate 1b:}

Photomicrograph of rat liver hepatocyte administered with $\mathrm{KBrO}_{3}$. The $\mathbf{C V}$ is congested with blood cells (mg $\mathrm{x} 200)$

Histological examination at the end of 20days period of potassium bromate administration when compared with their respective controls (Plates 1a, $2 \mathrm{a}$ and $3 \mathrm{a}$ ) revealed congestion of the central vein with blood cells in the hepatocytes (Plate 1b), infiltration of the interstitial cells accompanied with acute nephritis in the nephrons (Plate 2b) and mild mucosal dysfunction in the small intestine (Plate 3b).

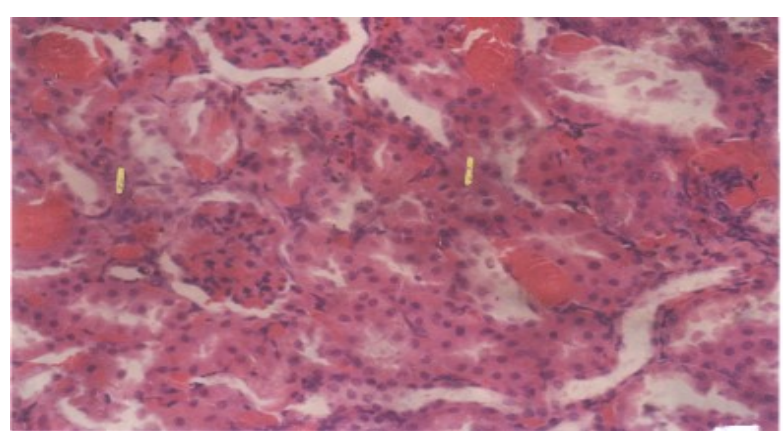

\section{Plate 2a:}

Photomicrograph of rat kidney (cortex) administered with distilled water for 20days. The area marked I represent normal intestitium (mg x200).

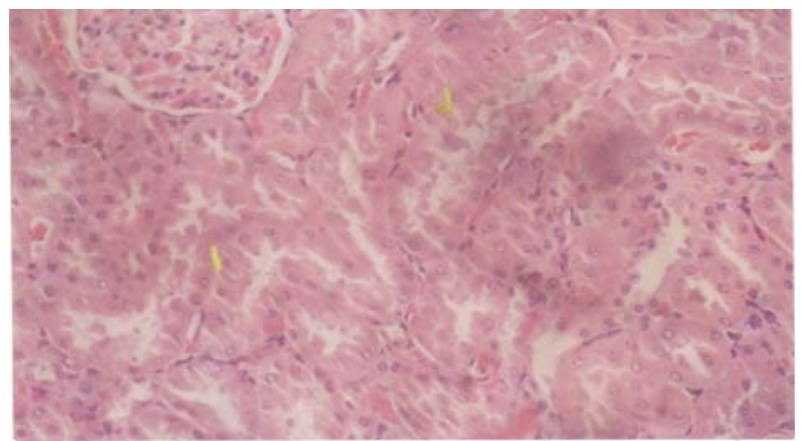

\section{Plate 2b:}

Photomicrograph of rat kidney (cortex) administered with $\mathrm{KBrO}_{3}$ for 20days. The marked area (I) shows infiltration of the interstitial cells engrossed with acute nephritis (mg x200).

\section{DISCUSSION}

The measurement of the activities of 'marker' enzymes in tissues and body fluids can be used in assessing the degree of assault and the toxicity of a chemical compound on organ/tissues (Malomo, 2000; Yakubu et al., 2003). Measurement of enzyme activities can also be used to indicate tissue cellular damage caused by a chemical compound long before histological changes (Akanji, 1986).

Alkaline phosphatase (ALP), a 'marker' enzyme for the plasma membrane and endoplasmic reticulum (Wright and Plummer, 1974; Shahjahan et al., 2004), is frequently used to assess the integrity of the plasma membrane (Akanji et al., 1993), such that any alteration in the activity of the enzyme in the tissue and serum 
would indicate likely damages to the external boundary of cells (plasma membrane) (Yakubu, 2006).

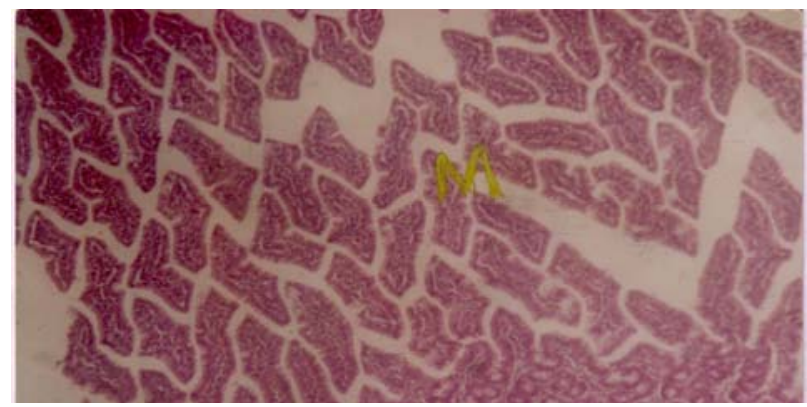

Plate 3a:

Photomicrograph of rat small intestine (duodenum) administered with distilled water for 20days. The area marked $\mathbf{M}$ represent normal architecture of the mucosal cells (mg x200).

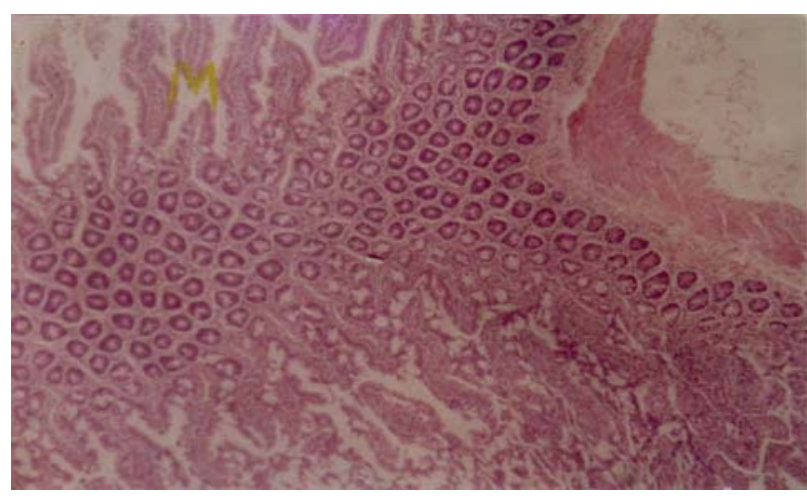

Plate 3b:

Photomicrograph of rat small intestine administered with $\mathrm{KBrO}_{3}$ for 20days. The marked area (M) shows disruption in the architecture of the mucosal cells (mg $\mathrm{x} 200)$.

The reduction in ALP activities following the administration of $\mathrm{KBrO}_{3}$ might be adduced to either loss of membrane components (including ALP) into the extracellular fluid, the serum (Malbica and Hart, 1971), inactivation of the enzyme molecule in situ (Umezawa and Hooper, 1982), or inhibition of the enzyme activity at the cellular/molecular level. It may also be due to a reduction in concentration or total absence of specific phospholipids required by this membranebound enzyme to express its full activity (Yakubu et al., 2002). Enzymes from diseased or damaged tissues may become recognisable in the serum presumably by leakage through altered cell membrane (Akanji and Ngaha, 1989). The corresponding increase in serum ALP activity confirmed that damage has been inflicted on the plasma membrane, which might have resulted in the compromise of its integrity (Yakubu et al., 2003). Such loss of ALP activity from the tissues could be attributable to disruption of the ordered lipid-bilayer of the membrane structure probably due to the presence of oxygen in the chemical compound, leading to escape of detectable quantity of ALP out of the cell into the extracellular fluid. The presence of oxygen in the chemical compound might have oxidised the polyunsaturated fatty acids which make up the lipid bilayer resulting in its disruption. Such reduction in the tissues' ALP activities would hinder adequate transportation of required ions or molecules across their cell membrane and this may lead to starvation of the cells (Akanji et al., 1993) and might also adversely affect other metabolic processes where the enzyme is involved such as the synthesis of nuclear proteins, nucleic acids and phospholipids as well as in the cleavage of phosphate esters (Yakubu, 2006). That there was no recovery by the tissues suggest a permanent toxicity by $\mathrm{KBrO}_{3}$ on the plasma membrane.

The increase in acid phosphatase activities, 'marker' enzyme of the lysosomal membrane (de Duve et al., 1962; Collins and Lewis, 1971) might be attributed to increase in functional activity of the tissues leading to de novo synthesis of the enzyme molecule in situ (Umezawa and Hooper, 1982; Yakubu et al., 2001) or loss of other proteins (Akanji et al., 1993; Akanji and Yakubu, 2000). This could result in indiscriminate hydrolysis of phosphate esters, which are potential energy source for the cell (Butterworth and Moss, 1966). This may suggest a possible threat to the well being of the organs as this may result in autolysis and consequently cell death. The fact that the there was recovery may imply that $\mathrm{KBrO}_{3}$ has transient and mild toxicity on the lysosomal membrane.

The significant loss of lactate dehydrogenase $(\mathrm{LDH})$, an enzyme associated with the cytosol (Philip, 1995) (Table 3) is quite understandable since it is in close proximity to the plasma 
membrane (Akanji and Yakubu, 2000). Slight damage to the plasma membrane will easily lead to leakage of $\mathrm{LDH}$ from the cell interior to the extracellular environment (Akanji et al ., 1993). However, the increase in serum LDH activity (Table 3) in this study supported the reasoning of leakage of the cytosolic enzyme from the tissues into the serum due to labialized plasma membrane.

GDH is a useful biochemical indicator of injury to the mitochondria (Henley et al., 1966). Mitochondria are the power plants of the cells because they contain many enzymes that together catalyze the oxidation of organic cell nutrients by molecular oxygen to yield carbon dioxide and water. Therefore, the significant reductions in activities of the enzyme (Table 4) are indications that the organelle has been adversely affected. This may imply reduction in the amount of energy being made available to the cells.

Histological examination of tissues could serve as complementary evidence to enzyme studies towards revealing any distortion/damage to the normal structure of the tissue cells. The incidence of congestion of cells displayed by the liver following administration of $\mathrm{KBrO}_{3}$ may be due to damage to the hepatocyte by the chemical compound. This is an indication of cirrhosis which usually disrupts the normal flow of blood through the liver (Singh, 2002). The inflammatory infiltration revealed on the kidney may be due to deposition of immune complexes probably generated by the chemical compound. The mild mucosal dysfunction on the small intestine may hamper the normal absorption of substance by the small intestine.

The results of this study thus indicate that chronic administration of potassium bromate might lead to labialization of the cell plasma membrane due to the presence of high oxygen content per molecule of potassium bromate. Such disruption of the ordered lipid bilayer of the plasma membrane has resulting in leakage of the enzymes to the extracellular fluid, the serum and this has corroborated by the histological studies. These alterations may account for the various adverse effects associated with potassium bromate administration.

\section{REFERENCES}

Akanji, M. A. (1986). A comparative biochemical study of the interaction of some trypanocides with rat tissue cellular system. Ph.D Thesis, University of Ife, Ile-Ife, Nigeria.

Akanji, M. A. and Ngaha, E. O. (1989). Effect of repeated administration of berenil on urinary excretion with corresponding tissue pattern in rats. Pharmacol. Toxicol. 64, 272-275.

Akanji, M. A., Olagoke, O. A. and Oloyede, $O$. B. (1993). Effect of chronic consumption of metabisulphite on the integrity of rat cellular system. Toxicol. 81: 173-179.

Akanji, M. A. and Yakubu, M. T. (2000). $\alpha-$ Tocopherol protects against metabisulphiteinduced tissue damage in rats. Nig. J. Biochem. Mol. Biol., 15(2): 179-183.

Butterworth, P. J. and Moss, D. W. (1966). The effect of urea on human kidney alkaline phosphatase. Biochem. J. 99: 9-10.

Collins, A. J. and Lewis, D. A. (1971). Lysosomal enzyme level in blood of arthritic rats. Biochem. Pharmacol., 28: 251-253.

De Angelo, A. B., George, M. H., Kilburn, S. R., Moore, T. M. and Wolf, D. C. (1998). Carcinogenicity of potassium bromate administered in the drinking water to male B6C3F1 mice and F344/N rats. Toxicologic Pathology, 26(5): 587-594.

de Duve, C. B. C., Wattiaux, R. and Baudhin, P. (1962). Distribution of enzyme between subcellular fractions in animal tissues. Adv. Enzymol., 24: 291-358.

Gornal, A. C., Bardawill, C. J. and David, M. M. (1949). Determination of serum protein by means of biuret reaction. J. Biol. Chem., 177: 751756.

Henley, K.S., Schmidt, E and Schmidt, E.W (1966) Enzymes in serum: Their uses in Diagnosis. Charles C. Thomas, Springfield. Pp. 54-73.

Krause, W. J. (2001). The art of examinig and interpreting histologic preparations. A student handbook. Partheton Publishing Group, UK. Pp. 910

Kurokawa, Y., Maekawa, A., Takahashi, M. and Hayashi, Y. (1990). Toxicity and 
carcinogenicity of potassium bromate- a new renal carcinogen. Environ. Health Perspect., 87: 309335.

Laba, O. (2003). NAFDAC: Battle-cry over Baker's use of unhealthy flour enhancer. This Day (March, 10 ${ }^{\text {th }}$ ed) 9: 2878, Pp. 58.

Mack, R. B. (1988). Round up he usual suspects. Potassium bromate poisioning. N. Carolina Med. J., 49: 243-245.

Mahajan, B. K. (1997). Significance of difference in means. In: Methods in Biostatistics for Medical and Research Workers, 6th edn. New Delhi: JAYPEE Brothers Medical Publishers, Pp. 130-155.

Malbica, J. O. and Hart, L. G. (1971). Effect of adenosine triphosphate (ATP) and some antiinflammatory agents on purified lysosomal fraction having high acid phosphatase and labile glucuronidase activity. Biochem. Pharmacol., 20: 2017-2026.

Malomo, S. O. (2000). Toxicological implication of ceftriaxone administration in rats. Nig. J. Biochem. Mol. Biol. 15(1): 33-38.

Ngaha, E. O. (1981). Renal effects of potassium dichromate in the rat: composition of urinary excretion with corresponding tissue pattern. Gen. Pharmacol., 12: 291.

Ngaha, E. O. (1982). Further studies on the in vivo and in vitro compound. Biochem. Physiol., 73: 109-113.

Philip, D. M. (1995). Plasma enzymes in diagnosis. In: Clinical Chemistry in Diagnosis and Treatment. $6^{\text {th }}$ edition. Arnold Publishers, London, Pp. 303-307.

Plummer, D. T. (1978). An introduction to practical Biochemistry. $2^{\text {nd }}$ Edition. McGraw-Hill, London. Pp. 144-145.

Schmidt, C., Schmidt, F. W., Hoin, D. and Gelarch, U. C. (1965). In: Methods of enzymatic analyses. Bergmeyer, H. U. (ed). Academic Press, NY. Pp. 651-712.

Shahjahan, M., Sabitha, K. E., Mallika, J. and Shyamala-Devi, C. S. (2004). Effect of Solanum trilobatum against carbon tetrachloride induced hepatic damage in albino rats. Indian J. Med. Res., 120: 194-198.

Singh, I. (2002). Textbook of human histology with colour atlas. $4^{\text {th }}$ edn., JAYPEE Publisher, India. Pp. 249-258.

Umezawa, H. and Hooper, I. R. (1982). Aminoglycoside antibiotic. Sranger-Verlag Berlin, Hadelberg, New York.

World Health Organization (WHO) (1996). Guidelines for drinking water quality. $2^{\text {nd }}$ ed. Vol. 2. Health criteria and other supporting information. Pp. 822-828.

Wright, P. J. and Plummer, D. T. (1974). The use of urinary enzyme measurement to detect renal damages caused by nephrotoxic compounds. Biochem. Pharmacol., 12: 65

Wroblewski, F. and La Due, J. S. (1955) Lactate dehydrogenase activity in blood. Proc. Soc. Exp. Biol. Med., 90: 210.

Wright, P. J., Leathwood, P. D. and Plummer, D. T. (1972a) Enzymes in rat urine. Alkaline phosphatase. Enzymologia, 42: 317-327.

Wright, P. J., Leathwood, P. D. and Plummer, D. T. (1972b) Enzymes in rat urine. Acid phosphatase. Enzymologia, 42: 459-462.

Yakubu, M. T. (2006). Aphrodisiac potentials and toxicological evaluation of aqueous extract of Fadogia agrestis (Schweinf. Ex Hiern) stem in male rats. Ph. D Thesis, University of Ilorin, Ilorin, Nigeria.

Yakubu, M. T., Akanji, M. A and Oladiji, A. T (2005) Aphrodisiac potentials of aqueous extract of Fadogia agrestis (Schweinf. Ex Heirn) stem in male albino rats. Asian Journal of Andology, 7(4): 399-404.

Yakubu, M.T., Akanji, M.A. and Salau, I.O. (2001) - Protective effect of ascorbic acid on some selected tissues of ranitidine - treated rats. Nig. J. Biochem. Mol. Biol. 16 (2): 177 - 182.

Yakubu, M. T., Olatunji, I. K. and Akanji, M. A. (2002). Comparative effects of administration of halofantrine hydrochloride and dihydroartemisinin on some enzymes of selected rat tissues. NISEB J., 2(3): 175-180.

Yakubu, M. T., Bilbis, L. S., Lawal, M. and Akanji, M. A. (2003). Effect of repeated administration of sildenafil citrate on selected enzyme activities of liver and kidney of male albino rats. Nig J Pure \& Appl Sci ., 18: 1395-400 